\title{
THE SECURITY OF THE KOREAN PENINSULA AND 20 YEARS OF DIPLOMATIC RELATIONS BETWEEN SOUTH KOREA AND RUSSIA
}

\author{
Park Chang Kyoo
}

\section{Introduction}

The year 2010 marked the $20^{\text {th }}$ Anniversary of the establishment of diplomatic relations between Republic of Korea and Russia. During this relatively short period of time, both countries have achieved remarkable progress in many areas. Since 1990, a total of 20 summits have been held, and leaders from Russia and Korea have made visits to see their counterparts nearly a dozen times. Trade volume, which stood at just $\$ 190$ million in 1992, grew to almost $\$ 10$ billion last year, an impressive 52-fold increase. Both tourism and travel have also increased sharply between the countries. Moreover, the relationship has been strengthened to become a "strategic cooperative partnership." However, despite these accomplishments the relationship still falls way short of our expectations. Some experts even say the friendship has declined and that passion to continue is dying. But we must not ignore this issue as the nation focuses on more pressing national interests. However attention has to be given to the current deadlock by getting rid of any obstacles in order to strengthen the relationship. Both sides first need to change their perception of each other. Although Russia's power in the international arena has weakened noticeably since the glory days of the Soviet Union, it is still one of the four big powers surrounding the Korean Peninsula. It is also a rapidly growing economic power with abundant energy and other natural resources. If we are concerned about the growing power of China in the region, we should realize the strategic value of Russia because it can counterbalance China. We should therefore reinforce our strategic partnership with Russia by keeping in mind its strategic significance until - and if - the divided Korean Peninsula unifies. From the perspective of Russia, Korea carries great strategic importance as a foothold to further advancement into the Pacific arena. A complementary economic partnership between the two countries can help Russia's development plan in eastern Siberia too.

As long as North Korea remains an "off-limits zone" - effectively blocking the free flow of workers and materials between Russia and South Korea, it will be difficult for the partnership between Moscow and Seoul to truly flourish. South Korea should also cooperate with Russia on issues such as North Korea's nuclear ambitions and potential reforms. These moves would represent significant steps toward developing a bond between Russia and South Korea that will last far into the future.

Historically, the Korean Peninsula has been the focus of Russia's attention since the twentieth century. Tsar Nicolas II, Lenin, Stalin, Brezhnev, and finally Gorbachev, for various reasons and in different forms, tried to get the advantage by aligning with 
the Korean peninsula. Gorbachev began with attempts to strengthen harmony with communist comrades in North Korea and ended up forging friendly links with Seoul by sacrificing alliance with Pyongyang. After the collapse of the USSR, Russia's policies toward Korea and Asia lost momentum for some time. The new Russian government was too focused in overcoming its internal problems, and any energy left for diplomacy was devoted to relations with the former parts of Soviet Union and with the West. It was believed that the future of Russian political economy depended greatly on the West for obtaining aid, and advice on various models of development. ${ }^{1}$

After the collapse of the Soviet Union, Russia faced an unprecedented challenge in forging new relationships in Northeast Asia. It had to transform the previous Soviet ideological basis into non-ideological post-Soviet reality on the Korean Peninsula. Russia was no longer allied with North Korea, and was pursing normal diplomatic relations with South Korea, despite the latter retaining a Cold War-era relationship with the US.

In the post-Soviet era, Russia was forced to develop new policies and relations with both Koreas as unlike other regions, the Korean peninsula remained divided as it had throughout the Cold War. ${ }^{2}$ Regardless of the dramatic changes in Europe, the basic structure of the Cold War system first established in the wake of World War Two continued to govern the Korean peninsula in the post-Soviet era. ${ }^{3}$ Ultimately, this led Russia to a Peninsula policy that was in constant flux, rather than one that remained fixed. ${ }^{4}$

The purpose of this paper is to review the progress of bilateral relations between South Korea and Russia, to locate both internal and external factors that regulate the two nations and look for a constructive outlook for the future based upon the above factors. The discussion will analyze the changes in the bilateral relations and followed by understanding problems that the two countries have faced during the buildup of diplomatic relations, and explores the future for a more robust relationship.

Since the establishment of the New Russia, Korea's political and diplomatic overtures toward Russia has undergone dramatic changes by former presidents; Roh Tae Woo, Kim Young Sam, Kim Dae Joong, Roh Moo Hyun, and the present president Lee Myung-bak. Moreover, South Korea's modification of its policy towards Russia was parallel with the changes in Kremlin's policy towards the Korean peninsula. This research will examine these processes of changes and distinctive features that emerged between South Korea and Russia by focusing on presidential policies of the two nations.

1 Eugene Bazhanov, Natasha Bazhanov, 'The Evolution of Russian-Korean Relations; External and Internal Factors', Asian Survey, Vol. 34, 1994, 789.

2 For an account of the meaning of the post-Soviet era towards the Korean Peninsula, see Lee Manwoo and Richard Mansbach, The Changing Order in Northeast Asia and the Korean Peninsula, Seoul: Kyungnam University Press, 1993.

3 As Bruce Cumings points out, 'the legacy of the Cold War still persisted on the Korean Peninsula after the collapse of the Soviet Union... It is a Museum of that [Cold War] awful conflict.' Michael Hogan, The End of the Cold War: Its Meaning and Implications, Cambridge: Cambridge University Press, 1992, pp. 98.

4 Youn Ikjoon, 'The Development of Russian-South Korean Relations under Yeltsin: In Search of Partnership Relations based on Treaties?', International Journal of Korean Unification Studies, Vol. 13, No. 2, 2004, pp. 122-123. 


\section{South Korea -Russian Relations under Roh Tae Woo}

\section{First Treaty between South Korea and Soviet Union}

Korean-Russian relations originated in the mid-19th century, when Imperial Russia and the Korean Kingdom officially established relations based on the Treaty of Trade and Commerce concluded on July 7, 1884. As a result of the Russian-Japanese War (1904-05), however, Imperial Russia and its successor the Soviet Union had no official relations with Korea until the end of World War Two. During the Cold War, the Soviet Union principally developed its bilateral relations with North Korea on the basis of the treaty of Friendship and Cooperation between Soviet Union and North Korea signed in 1961 (henceforth, the 1961 Soviet-North Korean Treaty). During the Gorbachev era, however, Soviet Korean policy gradually began to concentrate on building good bilateral relations with South Korea under the New Political Thinking. Conversely, Gorbachev's Korean policy still sought to retain influence over North Korea and observe the 1961 Soviet-North Korean Treaty. This meant that the Soviet Union under Gorbachev was attempting for the first time to establish active bilateral relations with both Koreas on the Korean Peninsula.

It is therefore essential to examine the wider context of emerging Soviet-South Korean bilateral relations when analyzing treaty issues, which during the Gorbachev era developed from economic agreements towards political ones. This formed the basis of the Soviet-South Korean Basic Treaty, one of the most important bilateral treaties between the two sides in the post-Soviet era. These developments in Soviet-South Korean relations finally resulted in diplomatic normalization in 1990, at which point the former Soviet Union became the first major power to recognize both independent nations on the Korean Peninsula. Thereafter, until the end of the Soviet Union in 1991, there were enormous bilateral developments between the two sides towards the conclusion of the political treaty (variously referred to as the "Treaty of Good Neighborhood, Partnership, and Cooperation between the Soviet Union and South Korea" or the "Treaty on GoodNeighborliness and Cooperation between the Soviet Union and South Korea"). In other words, a solid foundation was laid for the Russian-South Korean Basic Treaty during the late Gorbachev period - although this political treaty was never concluded due to the sudden attempted coup in Moscow in August 1991. There are two distinct stages leading to the political treaty: pre- and post diplomatic normalization.

These pre-diplomatic normalization efforts focused on improving Soviet-South Korean economic and non-governmental relations as a precondition for diplomatic normalization. In other words, it is clear that these steps became a collective foundation for the forthcoming Russian-South Korean Basic Treaty in the post-Soviet era. ${ }^{5}$ It clearly indicated Russia's pro-South Korean stance towards the Korean Peninsula, because this Treaty was concluded within a year of the collapse of the Soviet Union. In other words, the negotiations for this political treaty, initiated by Gorbachev and Roh Tae Woo during the late Soviet era, were continued by the Russian leadership after the Soviet disintegration. The result was full-scale diplomatic friendship and a political treaty, comparable to the 1961 Soviet-North Korean Treaty.

5 Youn Ikjoon, 'The Development of Russian-South Korean Relations under Yeltsin: In Search of Partnership Relations based on Treaties?', 2004, pp.125-127. 


\section{Relations of South Korea and Russian Federation}

Russia largely followed Gorbachev's late Korean policy, which was centered on economic interests on the Peninsula. To this end, Russia obviously placed priority on the development of relations with South Korea. In other words, Russia tried to develop its relations with South Korea through diplomatic normalization (1990) to partnership relations in the post-Soviet era. This can be separated into two stages: (1) the conclusion of the Russian-South Korean Basic Treaty; and (2) the development of bilateral agreements on military cooperation between Russia and South Korea.

The Russian-South Korean Basic Treaty was concluded during Yeltsin's visit to Seoul in November 1992. For example, the existing 1961 Soviet-North Korean Treaty had become a serious obstacle to concluding the Russian-South Korean Basic Treaty. In fact, from the beginning of 1992, the South Korean side demanded that Russia renounce the 1961 Soviet-North Korean Treaty as a pre-condition for the expansion of the economic relationship. In other words, South Korea demanded Russia break its bond with North Korea, which at least on paper retained the character of a military alliance. Throughout this period (Dec. 1991 - Dec. 1993), it was obvious that bilateral relations were fully focused on preparing and concluding this political treaty. Above all, high-level political-economic contacts between the two sides were frequent and primarily designed to discuss and coordinate the Russian-South Korean Basic Treaty, which was scheduled to be signed in the autumn (September) of 1992. Notably, in March 1992, Russian Foreign Minister, Andrei Kozyrev paid an official visit to South Korea. This marked the first serious phase of the preparations for Yeltsin's official visit. By the time of Kozyrev's visit to South Korea, the two countries had agreed the basic principles of the Treaty. ${ }^{6}$

There were further discussions on the draft of the Russian-South Korean Basic Treaty when the South Korean Foreign Minister visited Russia in June 1992. During the meeting, the two foreign ministers finalized almost all of the text of a bilateral treaty on their basic relations. Between November 18 and 20, 1992, Yeltsin finally paid an official visit to South Korea to formalize and strengthen the ties developed at the end of the Gorbachev years, and also to resolve the existing several problems that remained between the two countries. As scheduled, on November 19,1992, the two sides signed the historic Russian-South Korean Basic Treaty, which provided a framework for both countries in the post-Soviet era. ${ }^{7}$

The Russian-South Korean Basic Treaty committed the two sides to refrain from using force and to settle all disputes by peaceful means in accordance with the UN Charter. They agreed to hold regular meetings between the heads of state and members of the government to discuss bilateral relations and international issues of mutual concern. The two nations also signed an agreement on cultural cooperation and an agreement eliminating double taxation of incomes, in addition to a Memorandum of Mutual Understanding for 1993, facilitating the first direct exchanges between the Defense Ministries of Russia and South Korea. ${ }^{8}$

6 'Kozyrev Gives New Conference on ROK Trip', TASS International Service, 19 March, 1992 in FBISSOV 92-055, pp. 31.

7 'ROK Treaty Ratified', Radio Rossi Network, 29 April, 1993 in FBIS-SOV93-082, 20 April, 1993, pp. 39.

8 Pravda, 24 November, 1992, pp. 3. 
The conclusion of the Russian-South Korean Basic Treaty demonstrated the fundamental changes in Russian perceptions and goals in her foreign policy not only towards the Peninsula, but also to the international environment of Northeast Asia in the post-Soviet era. ${ }^{9}$

\section{Searching for the Military Cooperation between Two Nations}

Despite several problems between the two sides, after the conclusion of the RussianSouth Korean Basic Treaty in 1992, bilateral relations gradually expanded towards the conclusion of agreements and accords, especially in the military field. The focus of Russian-South Korean relations increasingly expanded from solely political relations to include military ones. Accordingly, active military contacts and exchange visits occurred between the two sides during this period; previously unthinkable during the Soviet era. For example, in early October 1992, an official Russian delegation, headed by Andrei Kokoshin, Russian First Deputy Defense Minister, arrived in Seoul. This was the first visit by a Russian military leader to South Korea. In return, General Yi Yangho, Chairman of the South Korean Armed Forces Joint Chiefs of Staff, visited Russia in September 1993 to strengthen mutual understanding and organize a military exchange between the two countries. Furthermore, the possibility of selling Russian arms to South Korea was also discussed. ${ }^{10}$

During the first Russian-South Korean summit in Seoul in November 1992, the two Ministers of Defense signed the Memorandum of Understanding and Measures to Develop Ties between the Defense Ministries of Russia and South Korea in 1993. Under this Memorandum, the two countries commenced the first direct military contacts. The military Memorandum envisaged delegationional exchanges at the level of Defense Ministers, Deputy Ministers, and heads of General Staff, and mutual visits by representatives of military schools and naval vessels. ${ }^{11}$ It should be emphasized that during the first summit in November 1992, Yeltsin assured South Korea that Russia would discontinue the provision of military assistance to North Korea, and supported South Korea's demand that North Korea should allow international inspections of its nuclear facilities. These measures described the fundamentals of Russian-South Korean military/security relations.

Military cooperation between the two sides under the Memorandum of Understanding had two significant implications. Firstly, the atmosphere of the Cold War on the Korean Peninsula seemed to be fading. In the post-Soviet era, the conclusion of bilateral political and military treaties signaled the intention of both sides to share the basic principles of the UN Charter and hold similar approaches to the problems of peace, disarmament, and building the new structure of multi-polar international relations as cooperative allied nations on the Korean peninsula.

Secondly, the beginning of military cooperation based on the Memorandum of Understanding would inevitably lead to a focus on the 1961 Soviet-North Korean Treaty, which defined the relations between the former Soviet Union and North Korea as Cold

9 Youn Ikjoon, 'The Development of Russian-South Korean Relations under Yeltsin: In Search of Partnership Relations based on Treaties?', 2004, pp.128-129.

10 Krasnaya Zvesda, 31 August, 1993, pp. 3.

11 'Defense Minister Sign Memorandum', ITAR-TASS, November 20, 1992 in FBIS-SOV 92-225, 20

November 1992, pp. 12. 
War allies. As Russia neared conclusion of a military treaty with South Korea, it had to re-define relations with North Korea under the 1961 Soviet-North Korean Treaty. ${ }^{12}$

Against this backdrop, Russian-South Korean military cooperation gained more momentum in 1993. In May, the signing of a Memorandum on Cooperation in Defense Industry between the South Korean Ministry of Trade, Industry, and Power-Engineering and the Russian Committee for the Defense Sectors of Industry signaled a specific step towards South Korean commercial involvement in transferring Russia's militaryoriented factories to peaceful production. In light of the new military cooperation, a Russian observer attended the joint US-South Korean "Team Spirit" military exercises for the first time in 1993. Russian Defense Minister Grachev stressed that in order to make practical steps in the military field it was necessary to set up working groups between the two Defense Ministries to plan events for the following year. His counterpart, General Lee noted that South Korea regarded Russia as a guarantor of stability in the Asia-Pacific Region (APR). The two sides agreed to conduct joint naval exercises. ${ }^{13}$

Russia's aims and interests in expanding its bilateral military cooperation with South Korea centered on two important factors: arms sales and conversion of its defense industry. The Russian leadership did not hide its official intentions about arms sales ${ }^{14}$ to South Korea because Moscow was unable to repay its loans to South Korea. In other words, Russia wanted to repay its economic debts to South Korea in the form of [defensive] arms transfers to South Korea instead of in monetary form. By concluding the military treaty with South Korea there would be no practical (or real) barriers to Russian arms sales to the ROK. In June 1993, for example, a South Korean official declared at the 3rd session of the Russian-Korean Committee for Scientific and Technical Cooperation that South Korea intended to purchase around 40 Russian high technologies. ${ }^{15}$

In the post-Soviet era, Russia's interest in expanding-bilateral ties with South Korea was also closely related to the conversion of its defense industry. ${ }^{16}$ Russia regarded South Korea as an ideal partner to assist in the conversion. In 1992, the South Korean government considered Russian proposals for military cooperation, and selected a number of projects in six fields: astronautics and outer space research; communications; transport and ground-based equipment; shipbuilding and maritime equipment; chemical production and chemical materials; and products of general designation. These spheres of cooperation included production of aircrafts, avionics, and testing of equipment; small engines for pilotless aircrafts; development of super-solid materials; ground-to-ship and ship-to-ship missiles; computer software and communication facilities. ${ }^{17}$

12 Youn Ikjoon, 'The Development of Russian-South Korean Relations under Yeltsin: In Search of Partnership Relations based on Treaties?', 2004, pp. 135.

13 Vladimir S. Miasnikov, 'Russian-South Korean Security Cooperation,' The Korean Journal of Defense Analysis, Vol. 6, No. 2, 1994.

14 For Russia's arms sales in the post-Soviet era, see Igor Khripunov, 'Russia's Arms Trade in the Post-Cold War Period,' Washington Quarterly, Vol. 17, No. 4, 1994.

15 'South Korea to Buy Russian High Technology', ITAR-TASS, 3 June, 1993 in FBIS-SOV 93-106, 4 June, 1993, pp. 21.

16 For the conversion of Russian defense industry, for example, see Laure Despres, 'Conversion of the Defense Industry in Russia and Arms Exports to the South,' Communist Economies and Economic Transformation, Vol. 6, No. 3, 1994.

17 L. Anosova and G. Matveyeva, South Korea: View from Russia, Moscow: Nauka Publishers, 1994. 
In the meantime, South Korean interests in expanding-bilateral military cooperation with Russia were mainly related to the political issue of North Korea. In other words, South Korea's interest in military treaties with Russia in the early 1990s related directly to the severe problem of North Korean nuclear development. Although there were some mutual advantages in military treaties, the development of Russian-South Korean military cooperation based on the Memorandum of Understanding remained heavily dependent on the US factors. ${ }^{18}$

\section{Discord in Bilateral Relationship under Kim Young Sam}

Although Russian-South Korean relations had been predominantly cordial and cooperative during this period, not everything was perfect. In 1993 the atmosphere in bilateral relations gradually began to deteriorate.

Russian reforms were encountering great difficulties. The economy was sliding towards a crisis, social conditions were deteriorating to a dangerous point, and political, social, and ethnic tensions rose to an unparalleled height in recent history. Almost half of the voters in the December 1993 parliamentary elections supported ultranationalists or communists. A conservative government emerged, which initiated "shock therapy" and restored some administrative-command methods of management to the Russian economy. In foreign affairs, stronger pressures by the Parliament and the militaryindustrial complex were expected to revise the pro-Western, pro-democratic stand of President Yeltsin. ${ }^{19}$ It was clear that Russian foreign policy had already become less romantic and more practical, less ideological (anticommunist) and more pragmatic, less internationalist and more nationalist, less pro-Western and more Eurasian, oriented to the East and South. Internal pressures and changing circumstances drove the Kremlin back to a more traditional diplomatic orientation towards security and great-power ambitions. Security concerns emerged at the forefront of Russia's Asian policy. Awareness grew in the Kremlin of a potential danger of renewed hostilities on the Korean Peninsula, and Moscow wanted to resume a more active role in mediating differences between Seoul and Pyongyang. Such an approach required an improvement of relations with the DPRK and a more balanced policy on the peninsula. ${ }^{20}$ Thus, the adoption of the "foreign policy concept" by the Yeltsin government in spring 1993 clearly indicated that Russian foreign policy was reorienting itself to Eurasianism. With the adoption of the fresh and innovative foreign policy concept, the Russian foreign policy community finally reached a consensus about Russia's foreign policy direction. ${ }^{21}$

The new foreign policy enunciated a set of foreign policy tasks and priorities as follows. First, th recognition that Russia's vital interests lay in developing full- scale relations with the other ex-Soviet republics. Thus, Russia's relations with the CIS states ("near abroad"), and to a lesser extent with east-central Europe, became the focal point of Russia's foreign policy. At the same time, the reassertion of strategic hegemony

18 Youn Ikjoon, 'The Development of Russian-South Korean Relations under Yeltsin: In Search of Partnership Relations based on Treaties?', 2004, pp. 138.

19 Eugene Bazhanov, Natasha Bazhanov, 'The Evolution of Russian-Korean Relations; External and Internal Factors', Asian Survey, Vol. 34, 1994, pp. 794.

20 Eugene Bazhanov, Natasha Bazhanov, 'The Evolution of Russian-Korean Relations; External and Internal Factors', 1994, pp. 795.

21 Suzanne Crow, 'Russsia Asserts Its Strategic Agenda,' RFE/RL Research Report, 17 December, 1993, pp. 1. 
(maintaining the sphere of influence) over these areas became the primary task of Russian foreign policy. Second, another important task of Russia's foreign policy was to form a belt of stability and neighborliness along its eastern and southern borders. In this context, the two Koreas were significant to Russian foreign policy to the extent that they constitute stable and friendly neighbors. With this in mind, Russia's foreign policy began to move away from idealism and economic determinism that focused on East-West cooperation and economic development, and move toward realpolitik and security determinism that emphasized an independent policy, security consideration, and national interests. ${ }^{22}$

\section{Estranged from Settlement of North Korean Nuclear Issue}

In late January 1993, Russian Deputy Foreign Minister Georgy Kunadze visited Pyongyang as a special representative of Yeltsin. The visit was intended to establish normal, good-neighborly relations between Pyongyang and Moscow. It was deemed necessary for Russia to maintain normal relations with both Koreas to maximize its national interests. Kunadze also reconfirmed that bilateral trade and economic cooperation would be on a purely commercial basis. Despite Moscow's desire to maintain a normal relationship with Pyongyang, bilateral ties remained tenuous and marginal, and Russia's ability to influence North Korea's nuclear program was not substantial.

Russia became increasingly frustrated because of its inability to control North Korea's nuclear issue and because of its alienation in the process of negotiating with North Korea. Russia expressed complaints about the October 1994 nuclear agreement between Washington and Pyongyang. In accordance with the agreement, an international consortium (KEDO, Korea Energy Development Organization) was created to implement economic and technical assistance to North Korea. The international consortium led by the U.S., South Korea, and Japan decided in principle to supply Pyongyang with two LWRs (Light Water Reactors) of a South Korean model. ${ }^{23}$ Russian commentators criticized the U.S. for not having consulted with Moscow in forming the international consortium. ${ }^{24}$ Aleksandr Panov, the deputy foreign minister, expressed Russia's misgivings about the U.S. treatment of Russia as a "junior partner" in the international consortium and even threatened to boycott the organization: "[Russia] may even refuse to join the organization which is being formed for this purpose by the United States, South Korea, and Japan, if it be only offered a secondary role in it. ${ }^{25} \mathrm{~A}$ Russian Foreign Ministry spokesman, pointing out North Korea's interest in acquiring Russian-model LWRs rather than South Korean-model LWRs, stated that the agreed framework damaged Moscow's commercial interests with its former Communist ally. ${ }^{26}$

22 Seung-Ho Joo, 'Russian Policy on Korean Unification in the Post-Cold War Era', Pacific Affairs, Vol. 69, 1996, pp. 33.

23 Seung-Ho Joo, 'Russian Policy on Korean Unification in the Post-Cold War Era', 1996, pp. 45.

24 Valeriya Sycheva, 'For Some They Are Terrorists but For Others They Are Partners,' The Kommersant Daily (Moscow), 10 January, 1995, A4.

25 'Russia Wants Large Role in Reforming North Korean Nuclear Program,' ITAR-TASS, 25 January, 1995

26 'Russia Unhappy over Geneva Nuclear Deal,' The Korea Herald, 17 November, 1994, pp. 2; Boris Konovalov, 'Russia Will Build Atomic Power Plant in Iran,' Izvestiya, 26 January, 1995, A2. 
Another significant limitation on the political and military relations during this period was the US and South Korean-led "Four-Party Talks," which created a new channel for discussing peace with North Korea, but excluded Russia (and Japan). Once again, this demonstrated the confines of Russian-South Korean cooperation, in both political and military arenas, while the US and South Korea reinforced their military alliance based on the 1953 US-South Korean Treaty.

Relations between Russia and South Korea entered an endurance test during this period. South Korea displayed dissatisfaction with Russia's policy of expanding and raising the level of political, economic, and cultural ties with North Korea. Furthermore, bilateral relations were seriously undermined by Russia's exclusion from the "Four-Party Talks." It was not surprising that during this period, Russian-South Korean relations proved to be very shaky indeed. ${ }^{27}$

\section{Economic Discord; Foreign Loan Redemption}

Secondly, Russia seemed to be dissatisfied with its economic cooperation with South Korea. Russian-South Korean trade continued to expand steadily, from US\$1.2 billion in 1992 to US\$1.57 billion in 1993 (Data of Korean Trade Center, 1992 and 1993), but problems over Russia's interest payment on this loan strained bilateral relations. More importantly, South Korea was less interested in improving relations with Russia than it had been with the Soviet Union in the late 1980s. This was reflected by two important developments: South Korea's New Diplomacy and Russia's loss of its influence in the international arena. ${ }^{28}$ Most problematic was Russia's inability or unwillingness to repay loans made by South Korea to the former Soviet Union (including Russia). As of June 1994, Russia owed South Korea $\$ 1.4$ billion, of which $\$ 400$ million was overdue debt. Russia offered several schemes for repayment, including with military hardware and technology and technology with enriched uranium. Although Moscow agreed to assume responsibility for repaying all of the loans to the former USSR, however, the two sides could not agree on the form and terms of repayment. ${ }^{29}$

\section{Purchasing Russian Military Weapons}

Thirdly, a Memorandum on Mutual Understanding with Regards to Military Contacts between the Defense Ministries of the Russian Federation and South Korea was signed when Russian Defense Minister, Pavel Grachev, visited South Korea in May 1995. The Memorandum of Understanding included the exchange of military experts and personnel, sharing military intelligence, and the South Korean purchase of Russian military equipment. This military agreement resulted in frequent contacts in the military arena. ${ }^{30}$ It was obvious that Russia was consistently more interested in expanding its economic relations with South Korea through these political and military agreements. Russia's primary motivation in establishing good bilateral relations with South Korea

27 Youn Ikjoon, 'The Development of Russian-South Korean Relations under Yeltsin: In Search of Partnership Relations based on Treaties?', 2004, pp. 148-150.

28 Youn Ikjoon, 'The Development of Russian-South Korean Relations under Yeltsin: In Search of Partnership Relations based on Treaties?', 2004, pp. 139.

29 'Tsueno Akaha, 'Russia in Asia in 1994: An Emerging East Asian Power', Asian Survey, Vol. 35, 1994, pp. 104,

30 'ROK Air Force Chief of Staff Arrives on Visit: Interest in MiG-29,' Moscow Voice of Russia World Service, May 22, 1995 in FBIS-SOV 95-100, 24 May, 1995, pp. 7. 
was purely economic. In this respect, Russian arms sales and debts to South Korea remained closely inter-related to bilateral agreements. Russia was primarily interested in selling arms to South Korea and in converting its defense industry with South Korean assistance. ${ }^{31}$

Nevertheless, there were obvious limitations to the development of further bilateral relations, in terms of both political and military cooperation. Above all, the US influenced bilateral relations, especially in political/military issues. For example, the US factor inevitably affected Russian arms sale to South Korea. The South Korean Defense Ministry discussed the possibility of using Russian armaments only for training and experimental programs, as South Korea had long focused on US armaments, which were incompatible with the Russian systems. More importantly, however, the South Korean side could not agree any further military relations with Russia without US consent. ${ }^{32}$ Russian-South Korean relations during this period included frequent contacts in most fields, although neither country was satisfied with the outcomes.

From a South Korean perspective, Russia no longer demonstrated the same degree of Soviet-era political influence over North Korea in reducing tensions on the Peninsula. For example, Russia had little influence on the North Korean nuclear issue, contrary to South Korean expectations, and in the post-Soviet era played no significant role in economic or security issues in Northeast Asia. As a result, South Korea increasingly focused on relations with China after the normalization of diplomatic relations. China became the second major power to recognize both Koreas on the Peninsula. ${ }^{33}$

\section{Stagnant Relations under Kim Dae-Jung and Putin}

\section{Putin's Korean Peninsula Policy}

In the 2000s, Russia's policy toward North Korea begun to reflect the overall pragmatic tone of Putin's foreign policy. Under his administration, Russia sought to open a new phase in relations with North Korea based on economic and regional cooperation. This approach was a response to new realities on the Korean Peninsula after the June 2000 inter-Korean summit and the Russo-North Korean summit in July. Putin also sought to realize Moscow's lingering aspirations to shape a constructive role for Russia in the Asia-Pacific region. Through renewed relations with North Korea, Russia attempted to promote a Moscow-Pyongyang-Seoul trilateral economic collaboration and, more broadly, to gain a pivotal role in Asia-Pacific economic cooperation. ${ }^{34}$

Putin's foreign policy centered on not only pragmatism but a symbiosis between a traditional pro-European orientation and institutionalized participation in the AsiaPacific community. ${ }^{35}$ Ivanov, the Russian foreign minister from September 1998 to March 2004, sought to build a nexus with Soviet- as well as pre-Soviet-era Russian foreign policy on the pragmatic basis of national interest. Improved relations with North

31 Youn Ikjoon, 'The Development of Russian-South Korean Relations under Yeltsin: In Search of Partnership Relations based on Treaties?', 2004, pp. 143-144.

32 Youn Ikjoon, 'The Development of Russian-South Korean Relations under Yeltsin: In Search of Partnership Relations based on Treaties?', 2004, pp. 146.

33 Youn Ikjoon, 'The Development of Russian-South Korean Relations under Yeltsin: In Search of Partnership Relations based on Treaties?', 2004, pp 138-140.

34 Alexander Vorontsov, 2002, 'Russia and the Korean Peninsula: Contemporary Realities and Prospects', Far Eastern Affairs, Vol. 30, No. 3, pp. 52.

35 Elizabeth Wishnick, 'Russia and China: Brothers Again?' Asian Survey, Vol. 41, No. 5,2001, pp. 800. 
Korea was expected to generate an opportunity to engage both Koreas economically, by participating, for example, in future projects linking Russia with the two Koreas. Specifically, Russia was interested in participating in the Trans-Siberian Railroad (TSR) project. For Seoul, connecting pipelines from Russia's Irkutsk region to South Korea via North Korea could lower current import prices by as much as $25 \%$, especially by obviating the need for expensive maritime transportation. ${ }^{36}$

Against this backdrop, Russia's renewed approach towards North Korea was part of Moscow's strategy of gaining a foothold in the Asia-Pacific region by finding an active role to play in economic globalization. ${ }^{37}$ This was a departure from Primakov's security-oriented approach, which aimed at strategically linking Russia with China and India..$^{38}$ The Putin administration took an alternative policy track toward regional economic cooperation that incorporated Japan, China, and both Koreas, via Putin's visit to Beijing, Tokyo, and Pyongyang in July 2000, participation in the APEC summit in November that year, and a Seoul visit in February in the following year. In particular, Russia pursued multilateral energy and transport projects, taking advantage of energy resources in the Russian Far East and eastern Siberia. This effort ultimately was aimed at building a new Northeast Asian economic community with Russia at its epicenter.

The discussion so far suggests that economic factors was and continued to be a major driving force in the Moscow-Pyongyang relationship in the 2000s. However, as mentioned earlier, there is a dualism attached to Putin's foreign policy that is designed to promote symbiosis-between Russia's economy and security, its strategic partnership with China and its position in the competition for regional influence, and between cooperation with the United States and Moscow's search for status as a global leader. Below, the discussion examines the notion that security still functions as one of the key factors in the Moscow-Pyongyang relationship. ${ }^{39}$

\section{Role of Russia as a Mediator}

Russia tried to emerge as an active mediator after North Korea initiated a nuclear crisis by admitting during a 2002 visit by U.S. Assistant Secretary of State James Kelly that it was still continuing its nuclear program. When Pyongyang announced on January 10, 2003, its withdrawal from the Non-Proliferation Treaty (NPT), Putin sent Vice Foreign Minister Alexandre Losyukov as his special envoy with a personal letter to Kim Jongil. Kim and Losyukov reportedly had a lengthy consultation over measures to end the nuclear problem peacefully, including the option of bilateral negotiations between Pyongyang and Washington and the possibility of obtaining a documented American guarantee that Kim Jong-il's regime would retain its power. Putin again supported the North Korean position after his September 27, 2003, summit meeting with his American counterpart at Camp David, asserting that the United States should give the Pyongyang regime a guarantee of security in exchange for the dismantling of its nuclear program.

36 Seung Ham Yang, Woosang Kim, Yongho Kim, 'Russo-North Korean Relations in the 2000s: Moscow's Continuing Search for Regional Influence', Asian Survey, Vol. 44, No. 6, 2004, pp. 801.

37 Mikhail Titarenko, 'Siberia and the Far East as the Strategic Base for Russia's Integration into the APR,' Far Eastern Affairs, Vol. 30, No. 4, 2002, pp. 46.

38 Leszek Buszynski, 'Russia and Northeast Asia: Aspirations and Reality,' Pacific Review Vol. 13, No. 3, 2000, pp. 399-420.

39 Seung Ham Yang, Woosang Kim, Yongho Kim, 'Russo-North Korean Relations in the 2000S: Moscow's Continuing Search for Regional Influence', 2004, pp. 802. 
In October, Russia reportedly opposed inclusion of the North Korean nuclear issue in the joint communique of the Association of Southeast Asian Nations summit (ASEAN).

Eventually, Russia regained its position as an influential regional actor through its participation in the Six-Party Talks. Russia's participation reflected its magnified influence over North Korea. Russia's search for a relevant role in the current nuclear issue is, in fact, a continuation of the "Putin formula." According to Vorontsov, Putin and Kim Jong-il agreed during Putin's visit to Pyongyang in July 2000 that Russia would launch two or three satellites annually on behalf of Pyongyang if North Korea would stop manufacturing missiles. This formula received favorable attention during Madeleine Albright's visit to Pyongyang in 2000, thereby signaling the return of Russia as one of the key players on the Korean Peninsula. ${ }^{40}$

In the meantime, Russia strengthened its power towards South Korea by applying North Korea's "Lever Strategy" which could be expressed as "Practical Equal Distance Policy". Putin's "Practical Distance Policy" was primarily based on limiting the power of Russia toward South Korea, and enhancing the value of North Korea, after pursuing the interest of Russia. In other words, Russia promoted a divided policy between the two Koreas. Russia emphasized on political-security aspect with the North and focused on economic advantages with the South. This reflected the diplomatic stance of Russia that she is not an outsider in the Korean Peninsula and that Moscow will play an important role as a powerful neighbour and promote relations in accordance to its interests and existence.

\section{Realistic Partnership between South Korea and Russia under Roh Moo Hyun}

The inauguration of Roh Moo Hyun's government in South Korea further exacerbated tensions in Washington-Seoul ties. Even before he came into office, anti-Americanism in South Korea emerged as a political issue after the accidental deaths of two 13-yearold girls who had been crushed by an American armored vehicle. The accident and the following large-scale candlelight demonstrations sparked broad anti-American feeling that peaked during the presidential campaign. As a candidate, Roh adopted an anti-American posture, stating that he had "no objection against anti-Americanism [and that Koreans] voice different opinions from those of the United States." He called for an apology from Bush, which was not offered. ${ }^{41}$

Whether the May 2003 U.S.-South Korean summit smoothed over all the differences between Seoul and Washington requires continued observance. During his U.S. visit, Roh reversed his anti-American stance, noting at an address to the Korea Society on May 13 that "I would have been in the political prisoners' camp had the United States not helped South Korea during the Korean War." ${ }^{42}$ Roh's pro-American behavior in Washington became somewhat reversed immediately after his return to Seoul, when Roh noted that his behavior in Washington had been a diplomatic choice in which he placed national interests ahead of his political faith. Despite Roh's seemingly proWashington gesture, Bush received him for only a brief time, in clear contrast to the invitation extended to Koizumi to join him at his Texas ranch. Moreover, the strained relations also saw Bush not visiting South Korea on his way home from Thailand after

40 Seung Ham Yang, Woosang Kim, and Yongho Kim, 'Russo-North Korean Relations in the 2000S: Moscow's Continuing Search for Regional Influence', Asian Survey, Vol. 44, No. 6, 2004, pp. 804-807. 41 Kyunghyang Daily News, Seoul, 19 May, 2003, pp. 4.

42 Donga Ilbo, 14 May, 2003, pp. 5. 
the APEC (Asia-Pacific Economic Cooperation) summit in October 2003. However, did visit Japan, the Philippines, Singapore, Indonesia, and Australia.

The Roh Moo-hyun administration moved in the direction of asserting greater independence while maintaining alliance ties with the United States through its assertion of greater "equality" in the alliance relationship and pursuit of "cooperative self-reliant defense" as a major tenet of its national security strategy. These efforts were built on a renewed sense of national pride and self-confidence in the idea that South Korea could now be an actor in regional security affairs rather than the object of great power rivalry that had characterized South Korea's situation for most of the twentieth century. In cooperation with the United States, Roh sought to re-establish sole operational control over South Korea's armed forces through dissolution of the Combined Forces Command and worked closely with the United States to support longstanding U.S. efforts to reconfigure its forces so as to play a supporting rather than a leading role in South Korea's defense. But Roh resisted U.S. efforts to promote trilateral cooperation with Japan for fear that such cooperation would launch a "second Cold War" in Asia and undermine inter-Korean reconciliation efforts.

Although Roh's style of managing relations with the United States was politically contested within South Korea and entailed costs in terms of distancing South Korea from the traditional protection it had enjoyed through close security relations with the United States, the Roh administration was able to work together with the Bush administration on many sensitive alliance issues, including the reconfiguration of U.S. forces, the dispatch of South Korean troops to Iraq, and negotiation (but not ratification) of a potentially strategically significant free trade agreement (FTA) with the United States.

One of the most important issues here is the existence of a fundamental difference in views over how to eliminate North Korea's nuclear program. Although the 2003 summit demonstrated that both governments were trying to narrow the perceptual gap in regards to the North Korea's nuclear program, Washington seemed willing to take the risk of involvement in an armed conflict, while Seoul wanted to avoid at all costs any military collision with Pyongyang. Unlike in 1994, South Korea now appeared far more reluctant to support the U.S. leadership in handling the issue.

In this sense, Russo-North Korean relations served as an effective channel to engineer Russian regional influence in Northeast Asia. Russia, as a legitimate actor in the regional affairs of Northeast Asia, would afford institutionalized reliability within the security assurance that a new dynamic would provide. In the new security concept, Russia emphasized the importance of the multilateral system to "reverse the trend toward transition from U.N. mechanisms to U.S. unilateralism." To block American hegemony, Russia displayed its willingness to establish strategic partnerships with both China and North Korea. ${ }^{43}$

\section{Multilateral System: The Six Party Talks}

Among the states in Northeast Asia, Russia has often been regarded as an exogenous actor with marginal influence in regional security affairs and excluded from various multilateral regional frameworks. The Six-Party Talks, a device to deal with the recent North Korean nuclear program issue among the United States, China, Japan, the two

43 Seung Ham Yang, Woosang Kim and Yongho Kim, 'Russo-North Korean Relations in the 2000S: Moscow's Continuing Search for Regional Influence', 2004, pp. 813-814. 
Koreas, and Russia, is the first instance since the dissolution of the Soviet Union that included Moscow as a legitimate negotiator in multilateral talks on the Korean Peninsula.

Russia was excluded from the Korean Peninsula Energy Development Organization (KEDO) project that was designed to provide North Korea with two light-water reactors and heavy oil, in return for termination of its nuclear program. KEDO was established as a result of the Agreed Framework between Washington and Pyongyang signed in October 1994. Russia's call for eight-party talks and provision of Russian-type nuclear reactors did not elicit favorable responses. Russia again was excluded from the Four-Party Talks that held six main sessions from April 1996 to August 1999; by that point, discussions had failed to reduce any feasible agreement. On the other hand, its involvement in the peninsula produced geopolitical and strategic by-products.

Russian involvement not only in the current Six Party Talks, but in future multilateral measures for resolving the North Korean nuclear issue have the potential to facilitate effective and peaceful settlement. Key factors, including a deadlock in bilateral U.S.-North Korean relations; Pyongyang's continued brinkmanship on disclosure of its possession of nuclear weapons and plans for continuing production; altered inter-Korean relations, along with signs of strains in Sino-North Korean relations, all contribute to the need for a greater Russian role in this region. Most importantly, Russian-North Korean relations entered a new era with the inauguration of Putin's administration. ${ }^{44}$

\section{Re-recognition of Russia}

During the Kim Dae Jung and Roh Moo Hyun periods, being independent from the U.S., South Korea emphasized on autonomy and balance in decision making in its foreign policy decision making. According to the international structural changes, South Korea tried to promote herself as key actor and increased diplomatic autonomy for peace and national prosperity in international relations. South Korea feels the necessity to strengthen its relations with Russia. There are two important reasons for a closer relationship with Russia.

First, from the $21^{\text {st }}$ century, Russia emerged as a great power nation in Eurasia, and has increasing significance in power and influence over other nations. During Putin's first administration, Russia harbored ambition to be a global super power through political stability and rapid economic growth. From then on, Russia tried to achieve diplomatic efforts in building advantage between the two Koreas. Putin's Korea Policy is the best practical tool to seek interests as well as promote a balance of power on the Korean Peninsula. For example, the Six Party Talk has allowed Russia to enhance its status in Northeast Asia.

Secondly, Russia recognized the value of developing and encouraging Korea to prosper economically, which in the end would protect its overall national interests on the peninsula. Being rich in natural resources, Russia has become one of the BRICs countries, boosting her existence in the world. Russia can play many roles on the Korean Peninsula. Firs, she can play a central role in pushing North Korea in dismantling its nuclear program. Secondly, her she can play the role in safeguarding the peninsula in preventing any military conflicts, and lastly, be a constructive mediator in resolving the North Korea's nuclear issue among great powers. Russia's wealth in natural

44 Seung Ham Yang, Woosang Kim and Yongho Kim, 2004, 'Russo-North Korean Relations in the 2000S: Moscow's Continuing Search for Regional Influence’', 2004, pp. 794-795. 
resources has played an important role as a gateway to developing and linking Eurasian transportation in the Far East and as a major supplier of natural resources to South Korea.

\section{Lee Myung-bak's Russian Policy}

Since his inauguration in February 2008 Lee Myung-bak has pursued a "pragmatic" foreign policy based on strengthening relationships with key regional powers and promoting conditional engagement with North Korea, while also enhancing South Korea's role in the international community. After ten years of rule by progressive administrations, Lee Myung-bak in February 2008, returned to South Korean conservatives to power on a platform of "pragmatism" and promises economic recovery. During his election campaign, Lee pledged to restore the alliance with the United States and campaigned on a policy of conditional engagement toward North Korea. This policy was formally known as the Initiative for Denuclearization and Opening up North Korea to Achieve US\$3000 in Per Capita Income (referred to as the DNO3000 policy), but this approach has proven impractical thus far as a starting point for progress in inter-Korean relations. Lee's policies represented a return to a traditional South Korean strategy of closely cooperating with the United States and maintaining a cautious and defensive approach toward North Korea (especially compared with the active engagement approaches of Kim Dae-jung and Roh Moohyun), while also reaching out to the international community in selected areas, such as "resource diplomacy.

Since Russia is both one of the four major powers and a major energy power, the potential and challenges of resource diplomacy might best be understood through an examination of Lee Myung-bak's visit to Moscow in September. Russia was the last of the four major powers that Lee visited, but the agenda in many respects has set the stage for what one might expect from the application of a "resource" focus to Korea's foreign relations. South Korea's relationship with Russia is the most distant and troubled of its interactions with the four major powers, and Russia's own interests and focus on the Korean peninsula has been intermittent, despite Russia's involvement in the Six Party Talks. The development of South Korea's relationship with Russia has proven more difficult than expected.

Nonetheless, Lee was able to schedule a summit meeting with his counterpart, President Dmitry Medvedev, as well as a meeting with Prime Minister Vladimir Putin, during September 2008. Lee's advertised accomplishments upon his return to Seoul were largely related to resource diplomacy. Specifically, the Russians agreed to South Korean participation in a natural gas pipeline that would facilitate gas exports to the South through North Korea by 2015. Other important diplomatic achievements highlighted in the 10-point joint summit statement by Lee and Medvedev includes a South Korea-only port near the North Korean-Russian border and a railroad project from which Lee described the economic benefits for the North as "far bigger than its previous cooperation projects with South Korea in Kaesong and at Mount Kumgang." While the joint projects with Russia are notable for largely involving North Korean participation, Lee also stressed that South Korea's strategic cooperative partnerships with Russia as well as China will be "very advantageous" to national security in case of an emergency on the Korean Peninsula. 
Although resource diplomacy has been one of Lee's core diplomatic principles since his February 2008 inauguration, South Korean experts have dismissed its apparent success as "overrated" based on a series of setbacks during his overseas visits. Lee was received in Moscow by an official lower in rank than proposed, prompting a public backlash from MOFAT on how differences in "diplomatic protocols" can lead to "public misunderstanding." The trans-North Korea gas pipeline, projected to carry at least 7.5 million tons of Russian natural gas annually for 30 years, has been touted as impractical, given that the decision was made without serious discussion. Earlier in June, Korea led the signing of an ambitious oil contract with Iraq's autonomous Kurdish government, but prospects remain unclear with Baghdad's intervention. Even before Prime Minister Han Seung-soo's April visit to Central Asia to lead Lee's resource diplomacy, South Korean envoys warned Seoul against the potential retaliation by host countries given the lack of full consultations prior to such efforts. For example, Korean ambassador to Kazakhstan Kil Il-soo argued for the need to "shape up adequate circumstances for that particular diplomatic stance" rather than "openly mention our interest in "resources diplomacy" to those resource-rich countries." 45

\section{Critiques of Russian Korean Experts opinion on Lee's Policy}

In the initial stages of Lee Myung-bak administration, Russia tried to make it clear its desire to seriously discuss the possibilities for improving the situation on the Korean peninsula by promoting peaceful dialogue and policies of taking into account North Korean's concerns. However, South Koreans insisted that peace and security could only be achieved with prior denuclearization of North Korea and shied away from accepting Russian logic of the promotion of cooperation with North Korea. Rep. Lee Jae oh, President Lee's envoy to Russia, noted in January 2008 that "Russian officials expressed support for the president elect's plan to forge a prosperous Northeast Asian economic community, especially as it will help in persuading North Korea to give up its nuclear weapons."

The Lee Myung-bak administration has so far failed to deepen cooperation with Russia on the North Korean issue: South Korean experts admit that "while the triangular alliance of the US ROK Japan has been strengthened with the inauguration of the Lee Myung-bak administration, diplomacy with Russia is restricted to only the field of energy and natural resources discussions." ${ }^{46}$ Russia, in the meantime, suggested that a committee as a communication channel between Seoul and Moscow to closely cooperate on the development of the Far East region be formed. However, initiatives to that effect remain distant. In the same way, the creation of and implementation of a trilateral committee (Russia-North Korea-South Korea) for discussions of issues related to economic cooperation seem to be an equally distant prospect.

Russia is concerned that the ROK conservative government might pay less attention to Moscow's interests, and, because of a deepening cooperation with the US conservative minded policy circles, may share a logic that sees the Russian role as that of merely an "interested observer," or merely supporting China on principal issues in Korean affairs, not playing an independent role. Washington is not happy with Russian statements that

45 Scott Snyder, 'Lee Myung-bak's Foreign Policy: A 250-Day Assessment', Journal of Defense Analysis, Vol. 21, No. 1, 2009.

46 Ryu Jin sook, 'Putin and Lee Myung-bak Sharing One Bed with Two Different Dreams?' Korean Institute for Future Strategies Bulletin, March 18, 2008. 
North Korea and the US share the fault for the 2008 stalling of the six party talks and that cannot but influence the ROK position and limit the possibilities for cooperation.

For one thing, Russia would not welcome a repetition of the situation seen in the 1990s, when South Korean representatives kept on urging the Russian government to exert pressure on Pyongyang and demanded information on Pyongyang's possible reactions and plans. At the same time, Russia would welcome a relaxation of tensions and deepening cooperation between North and South Korea and could render assistance to these efforts from both sides of the 38th parallel if needed. ${ }^{47}$

\section{Conclusion}

Even though South Korea and Russia hardly have had any meaningful interactions for the last 20 years, nonetheless both two countries have been making cooperative partnership in several fields; politics, economic, military and security. From these aspects, a positive evaluation can be summarized in relations between the two countries. However, there are some instability in starting of the process between South Korea and Russia. There are two obstacles for improving the relationship which includes internal as well as external factors.

The first feature of internal aspect is disharmony of mutual interests. At the beginning of the relation, Russia was eager to get politically compensated, and economy cost of pro-South Korea Policy. For your information, Soviet Union got \$ US 6 billion dollars in loan and \$ US 930 million dollars as investment from West Germany for promising tacitness about unification of the two Germany. Therefore, it is understandable that South Korea has to repay for Soviet's kindness to make diplomatic relation between South Korea and Soviet Union, which was performed even though North Korea opposed to the amity of South Korea and Soviet Union. It seems like that Russia was unsatisfied of the fact that, South Korea promised Soviet Union to pay \$ US 3 billion as an economic cooperative loan. However, after the collapse of Soviet Union, South Korea supported only half the amount of that was promised.

Moreover, Russia's political status began to be downgraded after the nuclear agreement between Washington and Pyongyang in October 1994. Excluding Russia from the military weapons market, international consortium KEDO (Korea Energy Development Organization) worsened the relationship between the two countries. These unbalanced mutual interest caused complications between both sides.

The second is disagreement of political priority in the Russian decision making process. At the beginning of diplomatic relations, South Korea put priority to ensure the relations between Russia and North Korea in military and security links is effectively cut off. However, Russia was more interested in economic developments, wishing South Korea would take a robust part in the Russian market.

Then, in other fields such as politics, military, and security, both nations differed widely. Politically, Russia wanted herself to be regarded as an equal to the U.S. or China in discussing various issues relating to the Korean Peninsula. However, South Korea just wanted Russia as a supporter in building a peaceful structure on the Korean Peninsula. Military issues also saw similar South Korean reactions. Russia was primarily interested in selling arms to South Korea and in converting its defense industry with

47 Georgy Toloraya, 'A Turn to the Right?' A Russian Comment on the North Korean Policy of ROK Conservative Government, International Journal of Korean Unification Studies, Vol. 17, 2008, pp. 84-85. 
South Korean cooperation, but South Korea only wanted personnel and educational interactions with the Russian military.

The first important external factor relates to the "division of Korea". Relations between South Korea and Russia are directly influenced by Russia's North Korea policy. The issue of a divided Korea cannot be seen independently from South Korea's relations with Russia. After Russia's normalization with North Korea, Russia has the capacity to promote interests as well as exert greater power over the Korean Peninsula. Russia's divided policy with both Koreas limits the political and economic relations between South Korea and Russia This will affect many of the projects between South Korea and Russia like that of the Trans Korean Railroad (TKR), Trans-Siberian Railroad (TSR), and the development of energy in the Far East Province of Russia. The status of these projects could alter according to developments in inter-Korean relations. Moreover, if North Korea suddenly becomes unstable, all projects would come to a halt.

Finally, the strategic structure of alliance between South Korea and the U.S should also be considered. As it is well known, the security of South Korea depends on the US. In such an environment, South Korean autonomy in international relations is severely limited. By wanting to improve Korean - Russian relations, South Korea has no choice but to take into consideration American responses to such a gesture. Fear of a negative reaction from the US could derail efforts at improving relations with Moscow. In other words, due to the presence of an exclusive relationship with the US, Korea is restrained in its interactions with Russia.

Despite all these complications, the future is positive for South Korea and Russia. There is more harmony than discord. Unlike with Japan or China, there are no territorial disputes, ethnic conflicts, or historical distrusts between South Korea and Russia. For these reasons, it is possible to productive a cooperative relation based on mutual understanding and interests. Economic structures of both countries are complementary, particularly when Russia desires South Korea's active participation in developing its Far East Province. Japan has no hope of developing the Russian Far East with Japan's assistance due to the protracted Northern Territory dispute. Moreover, Russian dealings with China has been affected by the constant demographical changes resulting from an influx of Chinese citizens in the Far East Provinces. Therefore, it is not surprising that South Korea has been acknowledged by Russia as a more credible main partner in developing the Russian Far East. 